\title{
Zenith and Nadir Passages of the Sun in Mesoamerica
}

\author{
Ivan Šprajc
}

Research Centre of the Slovenian Academy of Sciences and Arts (ZRC SAZU), Ljubljana sprajc@zrc-sazu.si

Among the astronomical phenomena occurring only in certain parts of the globe, the Sun's zenith and nadir passages stand out prominently, exemplifying the extent to which geographic latitude determines the significance attributed to particular celestial events and influences their role in cosmological concepts. The Sun reaches the zenith and the nadir (or anti-zenith) exclusively in tropical latitudes. On the Tropics of Cancer and Capricorn, these events coincide with the solstices, whereas in the intermediate belt each of the two phenomena occurs twice a year on dates that vary as a function of geographic latitude. The idea that the ancient Mesoamericans paid attention to both zenith and nadir Sun has long been very popular and different kinds of evidence have been claimed to reflect the significance of these phenomena. But how reliable is this evidence, and to what extent does it support these hypotheses?

\section{Significance of Zenith and Nadir Sun}

In the early twentieth century, Zelia Nuttall $(1928 ; 1931)$ argued that the Sun's zenith passages were observed throughout the tropical latitudes of the American continent, their significance being attributable to the fact that one of these two annual events marks the transition from the dry to the rainy season. She contended that the observations were made by means of vertical staffs, poles, stone monuments and even buildings with vertical walls, but her evidence for Mesoamerica was largely circumstantial. In particular, she interpreted a decree issued in 1577 by Philip II of Spain demanding that colonial authorities report - among other characteristics of their communities - their latitudes and dates of the Sun's zenith passage as having had the aim of suppressing pagan ceremonies associated with these events. She also referred to an erudite nineteenth-century Yucatec, Juan Pío Pérez, whose manuscript on Yucatec chronology was first published (in English translation) as an appendix in John L. Stephens' Incidents of Travel in Yucatan 
(1843, I: 434-47). He wrote that the ancient Maya commenced their calendrical year on 16th July, "having sought to make it begin from the precise day on which the sun returns to the zenith of this peninsula on his way to the southern regions" (Pérez, in Stephens 1843 , I: 436). In fact, the starting date of the calendrical year could not have been fixed by zenith passage dates, both because the Maya used the same calendar over an extensive area and because their 365-day year, due to the lack of intercalations, did not preserve a permanent concordance with the tropical year.

Nonetheless, it is not impossible that Pío Pérez's assumption and the above-cited requirement of the Spanish crown echoed the importance of solar zenith passages among the contemporary natives. This is indeed quite plausible, considering that the awareness of these phenomena has been ethnographically corroborated among some indigenous communities in the twentieth century (Lehmann 1928, 768; Remington 1980, 107; Villa Rojas 1986, 136). According to Vogt $(1997,111)$, the Tzotzil Maya from Zinacantan, in Chiapas, Mexico, even have a native name for solar zenith transits. The first annual zenith passage, occurring all over Mesoamerica between late April and June solstice, is particularly important, as it announces or coincides with the onset of the rainy season, which conditions the planting of maize. In lower latitudes, the second zenith passage is observed in early August and is sometimes associated with the ripening of the first maize cobs (Girard 1948, 49-66; 1949, 437-453; Tedlock 1991, 181-182, 185; 1992, 180, 189; Milbrath 1999, 13-17).

Since the interest in solar zenith passages has been documented in communities with notable survivals of the Mesoamerican cultural tradition, it is very likely that the Sun's zenith passages were observed in pre-Hispanic times, and certain archaeologically recovered devices discussed below support this opinion. On the other hand, the Sun's transit through the nadir is not observable; the day of this event could only have been determined indirectly, employing different procedures with varying degrees of precision (Sánchez Nava and Šprajc 2015: 55-56), but there is no compelling evidence that the Mesoamericans attempted to achieve this goal, notwithstanding various claims to the contrary.

Even the significance of zenith passage dates has often been overstated. While there is some evidence concerning the role of zenith and nadir in the Mesoamerican worldview (see below), many arguments advocating for the importance of the Sun's corresponding positions are based on indirect, ambiguous and sometimes erroneously interpreted data. For various calendrical records that have been presumed to mark the Sun's zenith and nadir passages, there is no contextual support indicating that this was, in fact, their purpose. Furthermore, a number of Mesoamerican languages lack discrete and unequivocal terms for north and south, but in some of them the two sections of the world are described as "up" and "down", or with some related terms referring to the Sun's daily motion (Watanabe 1983; Tedlock 1992, 177-178; Lipp 2005, 175). Based on this information, the points occupied by the Sun at noon and midnight, which are common temporal and spatial references in indigenous communities, have often been equated with the zenith and nadir, even though this equivalence was not explicitly reported by the informants, who simply referred to the highest and lowest positions the Sun reaches 
every day (e.g. Gossen 1984, 33; Knab 1991, 39, 43; Amador Naranjo 1995). It has also been argued that the Maya directional glyphs identified previously with north and south in fact refer to zenith and nadir, respectively (Bricker 1983; 1988; Stross 1991). In the light of advances in epigraphic research, however, it is now rather clear that these glyphs can be read phonetically as north and south (Lounsbury 1984, 179-180; Closs 1988a; 1988b; Justeson 1989, 119, 126 note 41; Hopkins and Josserand 2001). Aside from the terms for north and south, special words for zenith and nadir are reported in colonial Yucatec Maya dictionaries, and it has been argued that they had their Classic-period glyphic counterparts (Justeson 1989, 119, 126, note 41); it may be noted, however, that these terms refer to the centres of the earth and the sky, but not explicitly to the Sun's corresponding positions. Significantly, Bricker and Bricker $(2011,37)$ admit that no unambiguous references to solar zenith passages have been recognised in the Maya codices.

\section{Observational Practices}

Despite the caveats expressed above, there is sufficient evidence indicating the importance (if somehow less pronounced than commonly thought) of the solar zenith passages in Mesoamerica, leading us to consider possible observational techniques. There is little ethnographic data, and it is vague. The Tzeltal Maya from Oxchuc, Chiapas, Mexico, told Villa Rojas $(1986,136)$ that the Sun on certain days remains still for a few moments directly above the church, and Vogt $(1997,111)$ reported that the Tzotzil from the nearby Zinacantan were aware of the lack of shadows around the zenith passage dates. According to Girard $(1948,56)$, a Chortí priest in Guatemala determines the day when the Sun is "in the middle of the sky" by noting the lack of shadow cast by a vertical pole or stick, or even by his own body. The problem is that, while such simple techniques may have been employed in pre-Hispanic times, it is impossible for them to ascertain the exact zenith passage date. Tichy (1992) argued that three tower-like Maya buildings on the Yucatán peninsula served as shadow-casting devices marking solar zenith passages on consecutive dates; admittedly, their rather unique shapes and their roughly equidistant placement approximately along the same meridian call for attention (cf. Broda 2006), but again, their characteristics and relatively modest dimensions would have hardly allowed the zenith transit dates to be determined with precision (Aveni 1995, S77-S78).

More significantly, at several Mesoamerican archaeological sites buildings with vertical shafts leading to interior chambers have been found, as well as artificially modified caves with openings allowing the passage of solar rays around noon during certain periods of the year (Aveni and Hartung 1981; Soruco 1991; Morante López 1995; Aveni 2001, 40-41, 265-266; Schávelzon 2010; Espinasa-Pereña and Diamant 2012). An astronomical use of these spaces is suggested by the fact that, where the original elements are preserved or can be reliably reconstructed, the first and last entrances of solar rays occur on significant dates, frequently recorded by architectural orientations (Morante López 1995; Šprajc 2001, 273-274; Šprajc and Sánchez Nava 2015, 38-39). The observation of the zenith Sun, therefore, does not seem to have been a primary function of these devices, but it was likely one of them: in the chamber of Structure P at Monte Albán (Figure 1), in Cave 1 of Teotihuacan and in the caves of Tzinacamóztoc in Cantona, 
archaeological features are preserved which are illuminated on the zenith passage dates (Morante López 1995, 38-40, 57; Espinasa-Pereña and Diamant 2012, 592-593). It is thus conceivable that perishable markers were used in other cases.

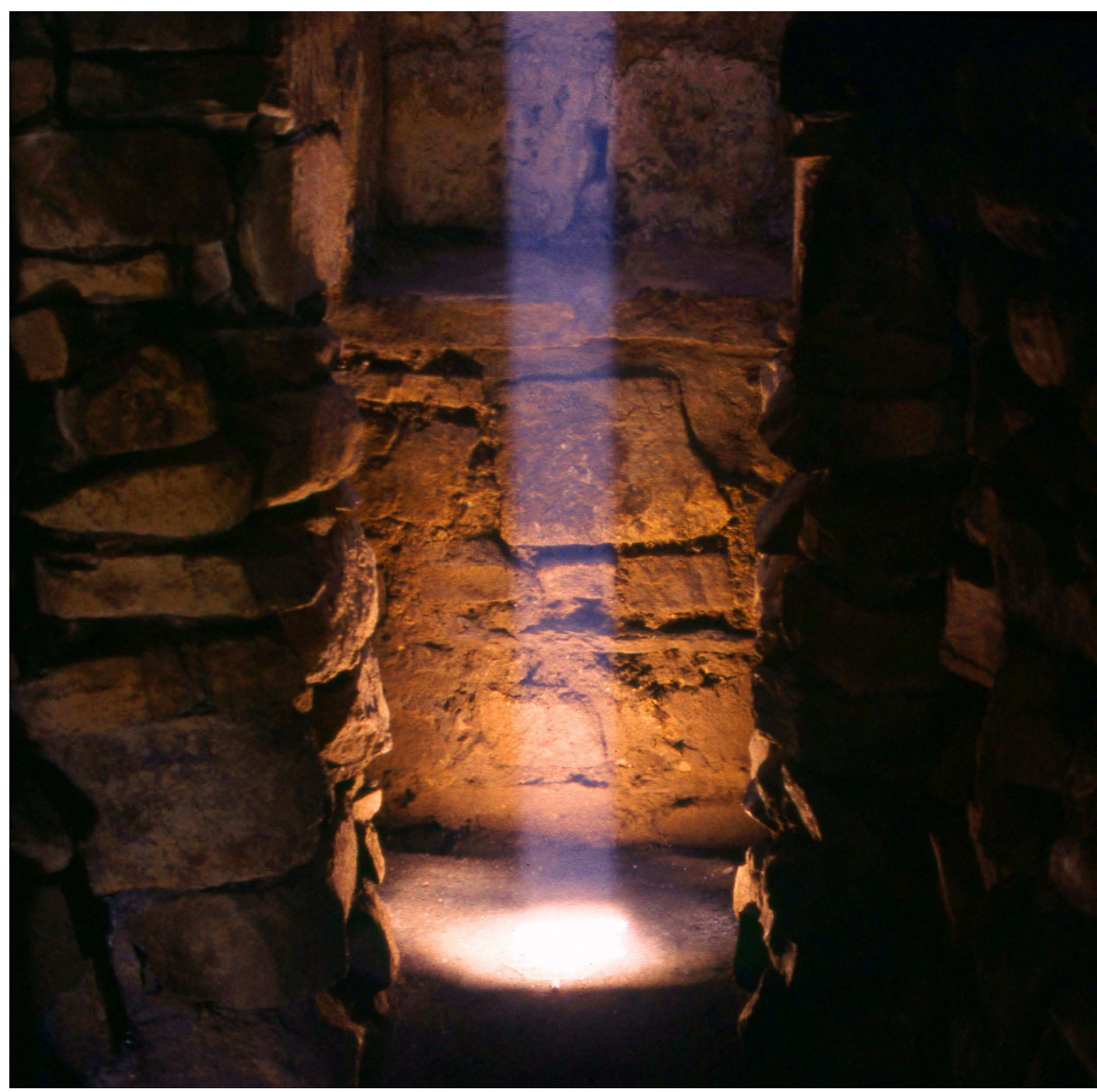

FIGURE 1. The Sun's rays on a zenith passage day falling into the chamber of Structure P at Monte Albán, Oaxaca, Mexico (photograph by I. Šprajc).

\section{Zenith and Nadir Sun on the Horizon?}

Soon after Nuttall's (1928; 1931) publications, Marquina and Ruiz (1932) proposed that the Mesoamerican buildings that are skewed about $17^{\circ}$ north of west recorded sunsets on the zenith passage days. Neither their interpretation nor their data were correct, but the idea that many structures were intended to record these events continues to be widely held. Also relatively widespread is the opinion that the Sun's horizon positions on the dates of its nadir transit were frequent alignment targets. Since the date of the Sun's passage through the zenith or nadir can be defined as the day when the difference between the absolute values of the Sun's declination and the local latitude comes to be nearest to $0^{\circ}$, both ideas have been tested by comparing the declinations recorded by orienta- 
tions with the latitudes of the corresponding sites. Figure 2 shows correlations between the two sets of values, obtained during recently accomplished systematic research of architectural orientations over most of the Mesoamerican area (Šprajc 2001; Sánchez Nava and Šprajc 2015; Šprajc and Sánchez Nava 2015; González-García and Šprajc 2016; Sánchez Nava et al. 2016; Šprajc et al. 2016).

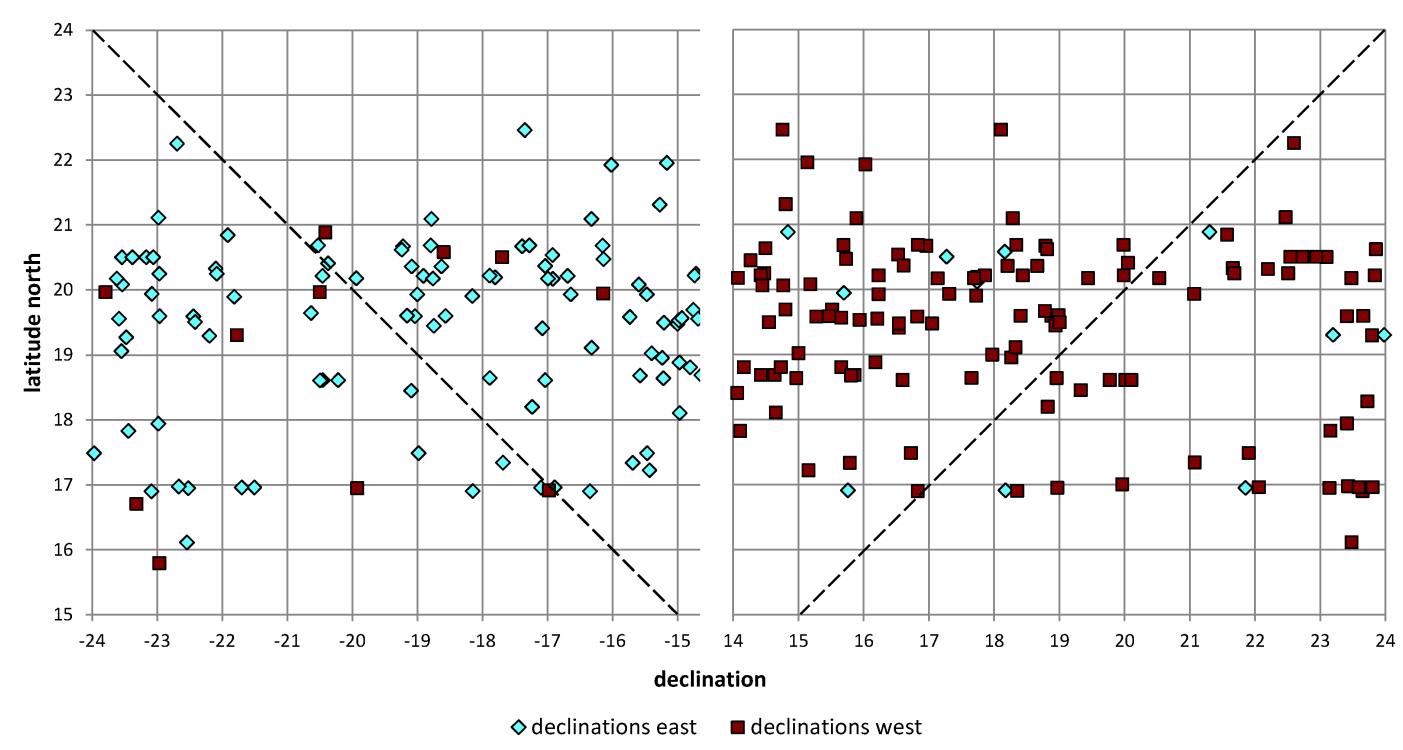

FIGURE 2. Correlations between declinations recorded by Mesoamerican architectural orientations and latitudes of sites (only declinations whose absolute values are within the range of Mesoamerican latitudes are shown).

The diagonal lines (dashed) connect the points with equivalent absolute values of declinations and latitudes, and so the declinations placed on or (considering their possible errors) near these lines might refer to the days of the Sun's zenith or nadir passage. Only a few points are placed in their immediate vicinity, and even in these cases the intent of recording the zenith or nadir passage days is improbable: considering that similar declinations are marked on differing latitudes (for example declinations around $-17^{\circ},-19^{\circ}$ or $20^{\circ}$ ), they must have a different rationale. Indeed, most of them belong to widespread and, therefore, latitude-independent orientation groups, whose significance has been explained in the studies cited above: the dates marked by solar orientations in Mesoamerica concentrate in four agriculturally significant seasons and, moreover, tend to be separated by multiples of 13 and 20 days. Since these are elementary periods of the Mesoamerican calendrical system, the orientations allowed the use of easily manageable observational calendars, which facilitated a proper scheduling of agricultural activities and associated ceremonies. Having a sample of hundreds of alignments, it is not surprising that in some cases the declinations recorded by orientations correspond quite closely to those of the local zenith or nadir. An illustrative example is El Castillo of Tulum, which (as well as the surrounding structures) is oriented almost precisely to the sunsets 
on the dates of the Sun's zenith passage (Galindo Trejo 1994, 170), but the same dates are recorded also at other sites, where they do not agree with these events (Sánchez Nava and Šprajc 2015, 55-57).

Several reasons may account for the persistence of ideas connecting orientations with the Sun's horizon positions on the zenith and nadir passage dates. Some of these proposals derive from inaccurate alignment data or local zenith passage dates. Others involve arbitrarily selected alignments, connecting either different construction elements of a single structure or various structures at a site (e.g. Fahmel Beyer 1992; Mendez and Karasik 2014; Slater 2014; Montero García 2016), or buildings and certain natural horizon features (e.g. Green 2014; Vadala and Milbrath 2016). Clearly, none of these hypotheses (unless based on erroneous data) can be dismissed outright, but objections can be raised on methodological grounds. Since the alignments they rely upon are of different types and no independent contextual data supports their putative astronomical function, none of the criteria required for their astronomically motivated function to be proposed with a reasonable confidence is fulfilled (cf. Aveni 2003; Šprajc 2005), raising the suspicion that the alignments were selected simply because they fit the hypothesis. If it has long been known that the important buildings all over Mesoamerica were oriented largely on astronomical grounds, it is because the azimuths of their main axes concentrate around certain values, a regularity that can only be explained with the use of astronomical references at the horizon (Aveni and Hartung 1986, 7-8). It is thus reasonable to suppose that, had the horizon positions of the zenith and nadir Sun been important references, they would have also been targeted by axial orientations. We could hypothesise, of course, that these specific dates were only recorded by alignments of special types. However, to test this hypothesis, a sound methodology should be devised, aimed at measuring and analysing a sample of typologically comparable alignments within a cultural complex.

One author who seems to have contributed to the popularity of ideas about the importance of sunrises and sunsets on the zenith transit dates is Rafael Girard (1948; 1949), who described the use of prominent horizon features as markers of these events among the Guatemalan Chortí. Although repeatedly cited and often uncritically accepted as relevant to understanding the pre-Hispanic worldview and related practices, his ethnographic information presents various inconsistencies and should be taken with caution. The use of horizon calendars among the Chortí was confirmed by Fought $(1972,386,435)$, but without any reference to the zenith passage days. More importantly, Girard's observational schemes involving the Sun's positions on the horizon on these dates are incompatible with astronomical reality, as already noted by Watanabe (1983, 721), and serious doubts have also been cast on other data presented by Girard (Lizardi Ramos et al. 1949; Starr 1951; Fought 1972, 58; Šprajc 2001, 113-118; Sánchez Nava and Šprajc 2015, 100-101). Given his readiness to "rectify" data that did not fit his hypotheses (Šprajc 2001, 114-115), combined with his statement that Marquina and Ruiz (1932) "have demonstrated that the natives oriented their monuments in accordance with a main axis that marked the sunsets on the day of its zenith passage" (Girard 1948, 64), one is entitled to wonder whether, or to what extent, it may have been this publication that influenced 
his ideas, attributed to the Chortí. It should be clarified that, as revealed by both other ethnographic accounts and archaeoastronomical alignment studies, the Mesoamericans did use horizon calendars. However, while the sunrises and sunsets over prominent mountain peaks at a number of sites occur on dates frequently marked by architectural orientations, the zenith passage dates are rarely among them.

Finally, not unrelated to the topic at hand is the question of the origin of the Mesoamerican 260-day calendrical cycle. One opinion is that it was invented near the latitude of $15^{\circ}$, where the solar zenith passage dates, 30th April and 13th August, are separated by 260 days. Since the orientations matching this pair of dates have long been known, it has been suggested that they were intended to record the zenith passage dates along that latitude, with one of their purposes also being to commemorate the base date of the Maya Long Count in 3114 BC (Malmström 1997; Aveni 2001, 144). However, several facts contradict this idea. First, the earliest dates of the 260-day count have not been found in the southern part of the Maya area, but rather in Oaxaca and Guerrero: one, securely dated to around $600 \mathrm{BC}$, is engraved on Monument 3 of San José Mogote (Flannery and Marcus 2015, 180-192), and another, even earlier, might be painted in the cave of Oxtotitlan (Whittaker 1983, 101). Secondly, the orientations marking 30th April and 13th August are earlier and more common in central and western Mexico than in the Maya area, where they do not seem to have appeared before the Classic period (Šprajc 2001; Sánchez Nava and Šprajc 2015, 79; Šprajc et al. 2016). And thirdly, considering that, aside from being significant in agricultural terms, the dates recorded by solar orientations are regularly spaced at calendrically significant intervals (one of the most widespread groups marks 12th February and 30th October, which are also separated by 260 days), it is this purpose that most likely accounts for the orientations correlating with 30th April and 13th August.

\section{Summary}

In tropical latitudes, the zenith passages are naturally significant moments of the Sun's apparent yearly motion and, just like the solstices, could have served as the most elementary references to keep track of the seasons. Considering the evidence discussed, the Mesoamericans observed these phenomena and were able to determine their dates with relatively sophisticated devices. However, few architectural orientations match the Sun's positions on the horizon on those days, making the intentionality of these correspondences hardly demonstrable, if not unlikely. Given the existence of widespread orientation groups, intended to record specific dates separated by calendrically significant intervals, the latitude-dependent zenith-passage days could have only rarely been incorporated in these observational schemes. It is possibly due to this fact that the Sun's zenith passages seem to have been not quite as important as traditionally believed.

The nadir probably had some symbolic significance, but the corresponding positions of the Sun are not observable and there is no unambiguous evidence that the dates of these events were determined. Even if we allow for errors that would have resulted from one or another indirect method that could have been employed, the few approximate correspondences between declinations and latitudes in Figure 2 lend little support to 
the idea that the Sun's horizon positions on the nadir passage dates were targeted by orientations.

\section{References}

Amador Naranjo, A., 1995. "La desaparición del Sol en Yucatán". In Religión y sociedad en el área maya, edited by C. Varela Torrecilla, J. L. Bonor Villarejo and M. Y. Fernández Marquínez, 311-317. Madrid: Sociedad Española de Estudios Mayas.

Aveni, A. F., 1995. "Frombork 1992: Where Worlds and Disciplines Collide". Archaeoastronomy: Supplement to the Journal for the History of Astronomy 20: S74-S79. https://doi.org/10.1177/002182869502602007

Aveni, A. F., 2001. Skywatchers: A Revised and Updated Version of Skywatchers of Ancient Mexico. Austin: University of Texas Press.

Aveni, A. F., 2003. "Archaeoastronomy in the Ancient Americas". Journal of Archaeological Research 11 (2): 149-191. https://doi.org/10.1023/A:1022971730558

Aveni, A. F. and H. Hartung, 1981. "The Observation of the Sun at the Time of Passage through the Zenith in Mesoamerica". Archaeoastronomy: Supplement to the Journal for the History of Astronomy 3: S51-S70.

Aveni, A. and H. Hartung, 1986. Maya City Planning and the Calendar. Transactions of the American Philosophical Society 76 (7). Philadelphia: American Philosophical Society.

Bricker, H. M. and V. R. Bricker, 2011. Astronomy in the Maya Codices. Memoirs of the American Philosophical Society 265. Philadelphia: American Philosophical Society.

Bricker, V. R., 1983. "Directional Glyphs in Maya Inscriptions and Codices". American Antiquity 48 (2): 347-353. https://doi.org/10.2307/280455

Bricker, V. R., 1988. "A Phonetic Glyph for Zenith: Reply to Closs". American Antiquity 53 (2): 394-400. https:// doi.org/10.2307/281028

Broda, J., 2006. "Zenith Observations and the Conceptualization of Geographical Latitude in Ancient Mesoamerica: A Historical Interdisciplinary Approach". In Viewing the Sky through Past and Present Cultures: Selected Papers from the Oxford VII International Conference on Archaeoastronomy, edited by T. W. Bostwick and B. Bates. Pueblo Grande Museum Anthropological Papers 15: 183-212. Phoenix, Arizona: City of Phoenix Parks and Recreation Department.

Closs, M. P., 1988a. "A Phonetic Version of the Maya Glyph for North". American Antiquity 53 (2): 386-393. https://doi.org/10.2307/281027

Closs, M. P., 1988b. "Response to Coggins and Bricker". American Antiquity 53 (2): 402-411. https://doi. org/10.2307/281030

Espinasa-Pereña, R., and R. Diamant, 2012. "Tzinacamóztoc, Possible Use of a Lava Tube as a Zenithal Observatory near Cantona Archaeological Site, Puebla, Mexico". Latin American Antiquity 23 (4): 585-596.

Fahmel Beyer, B., 1992. "El complejo de observación cenital en Monte Albán: Historia de una institución". In Antropología mesoamericana: Homenaje a Alfonso Villa Rojas, edited by V. M. Esponda Jimeno, S. Pincemin Deliberos and M. Rosas Kifuri, 529-545. Tuxtla Gutiérrez, Mexico: Gobierno del Estado de Chiapas and Instituto Chiapaneco de Cultura.

Flannery, K. V. and J. Marcus, 2015. Excavations at San José Mogote, vol. 2: The Cognitive Archaeology. Ann Arbor: University of Michigan.

Fought, J. G., 1972. Chorti (Mayan) Texts, vol. 1. Philadelphia: University of Pennsylvania Press.

Galindo Trejo, J., 1994. Arqueoastronomía en la América antigua. Mexico City: CONACYT and Editorial Equipo Sirius.

Girard, R., 1948. El calendario maya-mexica: Origen, función, desarrollo y lugar de procedencia. Mexico City: Editorial Stylo.

Girard, R., 1949. Los chortis ante el problema maya, vol. 2. Guatemala: Ministerio de Educación Pública.

González-García, A. C. and I. Šprajc, 2016. "Astronomical Significance of Architectural Orientations in the Maya Lowlands: A Statistical Approach". Journal of Archaeological Science Reports 9: 191-202. https:// doi.org/10.1016/j.jasrep.2016.07.020

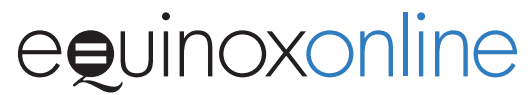


Gossen, G. H., 1984. Chamulas in the World of the Sun: Time and Space in a Maya Oral Tradition. Prospect Heights, New York: Waveland Press (first published by Harvard University Press, 1974).

Green, H. H., 2014. "Cosmic Order at Chocolá: Implications of Solar Observations of the Eastern Horizon at Chocolá, Suchitepéquez, Guatemala". In Archaeoastronomy and the Maya, edited by G. Aldana y Villalobos and E. L. Barnhart, 17-39. Oxford: Oxbow Books.

Hopkins, N. A. and J. K. Josserand, 2001. "Directions and Partitions in Maya World View" [online]. Crystal River, Florida: Foundation for the Advancement of Mesoamerican Studies. Accessed February 2017, http://www.famsi.org/research/hopkins/directions.html\#intro

Justeson, J. S., 1989. "Ancient Maya Ethnoastronomy: An Overview of Hieroglyphic Sources". In World Archaeoastronomy, edited by A. F. Aveni, 76-129. Cambridge: Cambridge University Press.

Knab, T. J., 1991. "Geografia del inframundo". Estudios de Cultura Náhuat/ 21: 31-57.

Lehmann, W., 1928. “Ergebnisse einer mit Unterstützung der Notgemeinschaft der Deutschen Wissenschaft in den Jahren 1925/1926 ausgeführten Forschungsreise nach Mexiko und Guatemala: 1. Mixe-Mythen". Anthropos 23: 749-791.

Lipp, F. J., 2005. "Mixe Calendrics, Ritual and Astronomy". In Songs from the Sky: Indigenous Astronomical and Cosmological Traditions of the World, edited by V. D. Chamberlain, J. B. Carlson and M. J. Young, 173-179. Austin: University of Texas Press / Leicester, UK: Ocarina Books.

Lizardi Ramos, C., A. Villa Rojas and I. Bernal, 1949. Review of Rafeael Girard, Los Chortis ante el problema maya. - Historia de las culturas indígenas de América, desde su origen hasta hoy. Colección Cultura Precolombina. México, 1949. Boletín Bibliográfico de Antropología Americana 12 (2): 19-31.

Lounsbury, F. G., 1984. "Glyphic Substitutions: Homophonic and Synonymic". In Phoneticism in Mayan Hieroglyphic Writing, edited by J. S. Justeson and L. Campbell. Institute for Mesoamerican Studies Publication 9: 167-184. Albany: Institute for Mesoamerican Studies, State University of New York.

Malmström, V. H., 1997. Cycles of the Sun, Mysteries of the Moon: The Calendar in Mesoamerican Civilization. Austin: University of Texas Press.

Marquina, I. and L. R. Ruiz, 1932. "La orientación de las pirámides prehispánicas". Universidad de México 5 (25-26): 11-17.

Mendez, A. and C. Karasik, 2014. “Centering the World: Zenith and Nadir Passages at Palenque". In Archaeoastronomy and the Maya, edited by G. Aldana y Villalobos and E. L. Barnhart, 97-110. Oxford: Oxbow Books.

Milbrath, S., 1999. Star Gods of the Maya: Astronomy in Art, Folklore, and Calendars. Austin: University of Texas Press.

Montero García, I. A., 2016. "Astronomy, Architecture and Caverns". In The Role of Archaeoastronomy in the Maya World: The Case Study of the Island of Cozumel, edited by N. Sanz, C. Connaughton, L. Gisbert, J. Pulido Mata and C. Tejada, 85-109. Mexico City: UNESCO Office in Mexico. http://unesdoc.unesco.org/ images/0024/002447/244721e.pdf, accessed March 2018.

Morante López, R. B., 1995. "Los observatorios subterráneos". La Palabra y el Hombre: Revista de la Universidad Veracruzana 94: 35-71.

Nuttall, Z., 1928. La observación del paso del sol por el zenit por los antiguos habitantes de la América tropical. Publicaciones de la Secretaría de Educación Publica 17 (20). Mexico City: Talleres Gráficos de la Nación.

Nuttall, Z., 1931. "Die mythologische Bedeutung des Sonnendurchganges durch den Zenit und die Art seiner Beobachtung bei den Ureinwohnern des tropischen Amerika". El México Antiguo 3 (1-2): 1-12.

Remington, J. A., 1980. "Prácticas astronómicas contemporáneas entre los mayas". In Astronomía en la América antigua, edited by A. F. Aveni, 105-120. Mexico City: Siglo XXI. Translation of J. A. Remington, 1977, "Current Astronomical Practices among the Maya", in A. F. Aveni, Native American Astronomy, 77-88. Austin: University of Texas Press.

Sánchez Nava, P. F. and I. Šprajc, 2015. Orientaciones astronómicas en la arquitectura maya de las tierras bajas. Mexico City: Instituto Nacional de Antropología e Historia.

Sánchez Nava, P. F., I. Šprajc and M. Hobel, 2016. Aspectos astronómicos de la arquitectura maya en la costa nororiental de la península de Yucatán. Prostor, kraj, čas 13. Ljubljana: Založba ZRC. http://iaps.zrc-sazu. si/sites/default/files/pkc13_sprajc.pdf, accessed March 2018.

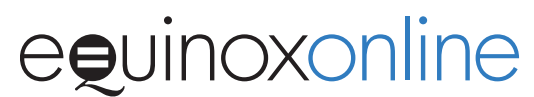


Schávelzon, D., 2010. “¿Un observatorio no observado?: Un edificio de Monte Albán según los primeros arqueólogos". Estudios Mesoamericanos: Revista del Programa de Posgrado en Estudios Mesoamericanos (nueva época) 9: 75-83.

Slater, D. A., 2014. "Linking Cave, Mountain, and Sky: A Subterranean Observation Point for the Sunrise on the Day of Solar Zenith Transit in Yucatan, Mexico". Latin American Antiquity 25 (2): 198-214. https://doi. org/10.7183/1045-6635.25.2.198

Soruco, E., 1991. "Una cueva ceremonial en Teotihuacán y sus implicaciones astronómicas religiosas". In Arqueoastronomía y etnoastronomía en Mesoamérica, edited by J. Broda, S. Iwaniszewski and L. Maupomé, 291-296. Mexico City: Universidad Nacional Autónoma de México.

Šprajc, l., 2001. Orientaciones astronómicas en la arquitectura prehispánica del centro de México. Mexico City: Instituto Nacional de Antropología e Historia.

Šprajc, I., 2005. "More on Mesoamerican Cosmology and City Plans". Latin American Antiquity 16 (2): 209-216. https://doi.org/10.2307/30042812

Šprajc, I. and P. F. Sánchez Nava, 2015. Orientaciones astronómicas en la arquitectura de Mesoamérica: Oaxaca yel Golfo de México. Prostor, kraj, čas 8. Ljubljana:Založba ZRC. http://iaps.zrc-sazu.si/sites/default/files/ pkc08_sprajc.pdf, accessed March 2018.

Šprajc, I., P. F. Sánchez Nava and A. Cañas Ortiz, 2016. Orientaciones astronómicas en la arquitectura de Mesoamérica: Occidente y Norte. Prostor, kraj, čas 12. Ljubljana: Založba ZRC. http://iaps.zrc-sazu.si/sites/ default/files/pkc12_sprajc_0.pdf, accessed March 2018.

Starr, B., 1951. "The Chorti and the Problem of the Survival of Maya Culture". American Anthropologist 53 (3): 355-369. https://doi.org/10.1525/aa.1951.53.3.02a00050

Stephens, J. L., 1843. Incidents of Travel in Yucatan, 2 vols. New York: Harper \& Brothers.

Stross, B., 1991. "Classic Maya Directional Glyphs". Journal of Linguistic Anthropology 1 (1): 97-114. https:// doi.org/10.1525/jlin.1991.1.1.97

Tedlock, B., 1991. "La dialéctica de la agronomía y astronomía maya-quichés". In Arqueoastronomía y etnoastronomía en Mesoamérica, edited by J. Broda, S. Iwaniszewski and L. Maupomé, 179-192. Mexico City: Universidad Nacional Autónoma de México.

Tedlock, B., 1992. Time and the Highland Maya (Revised edition). Albuquerque: University of New Mexico Press.

Tichy, F., 1992. "Las torres en la región de Chenes y el meridiano de Uxmal". Cuadernos de Arquitectura Mesoamericana 19: 45-52.

Vadala, J. R. and S. Milbrath, 2016. "Using Virtual Reality to Understand Astronomical Knowledge and Historical Landscapes at Preclassic Cerros, Belize". Journal of Skyscape Archaeology 2 (1): 25-44. https://doi. org/10.1558/jsa.v2i1.26915

Villa Rojas, A., 1986. "Los conceptos de espacio y tiempo entre los grupos mayances contemporaneos". In Tiempo y realidad en el pensamiento maya, by M. León-Portilla (2nd edition), 119-167. Mexico City: Universidad Nacional Autónoma de México.

Vogt, E. Z., 1997. "Zinacanteco Astronomy". Mexicon 19 (6): 110-117.

Watanabe, J. M., 1983. "In the World of the Sun: A Cognitive Model of Mayan Cosmology". Man (new series) 18 (4): 710-728. https://doi.org/10.2307/2801904

Whittaker, G., 1983. "The Structure of the Zapotec Calendar". In Calendars in Mesoamerica and Peru: Native American Computations of Time, edited by A. F. Aveni and G. Brotherston. British Archaeological Reports, International Series 174: 101-133. Oxford: British Archaeological Reports.

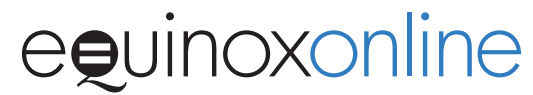

